\title{
Capacity Building and Public Service Delivery in Nigeria: A Critical Appraisal
}

\author{
Godwin Ihemeje \\ Albany State University \\ Salami Afegbua \\ Lagos State University
}

\begin{abstract}
The essence of government at whatever levels is to ensure efficient service delivery to the citizenry. Efficient service delivery depends largely on the training, expertise and entire staff development. Mediocrity, redundancy, low level of productivity and inefficiency are some of the features in the Nigerian civil service that have impaired viable capacity building in the public sector. There is a nexus between staff development, capacity building and service delivery. Appropriate skills, knowledge and ideas can be acquired through seminars, workshops and training. The acquisition of these skills will help to equip civil servants to perform their daily routines and tasks in the most efficient manner. This paper therefore takes a critical examination of capacity building in the Nigerian civil service with the view to re-invigorating the service to meet the challenges of the $21^{\text {st }}$ century. It utilizes historical and descriptive approach to analyze the patterns of public service delivery in Nigeria. The paper concludes that capacity building in the public sector has been subjected to numerous critical analyses; while particular attention should be focused on how more empirical works are to be carried out and more resources can be deployed in public sector capacity building in the country.
\end{abstract}

Keywords: Public Service, Capacity Building, Service Efficiency, Challenges

DOI: $10.7176 /$ PPAR/10-4-04

Publication date: April $30^{\text {th }} 2020$

\subsection{Introduction}

Evidences abound that there is a relationship between capacity building and efficient service delivery. The public sector, the major employer of labour and the sole institution for national growth and development in Nigeria is better positioned to attract and retain vibrant and skilful labour force that would facilitate the transformation of government policies and actions into concrete reality (Aborisade \& Aransi, 2006).

Capacity building in a country like Nigeria has consistently posed serious challenges over the decades. The post-independent civil service has not sufficiently promoted capacity building and this has resulted in poor organizational performance and service delivery. The civil service of any nation remains critical to national development, integration and continuous growth, especially developing countries like Nigeria. The service plays critical role in galvanizing the nation and its resources to development. The dearth of professionals in the Nigerian civil service has impaired socio-economic political development. The human factor is indisputably acknowledged as a critical factor in the development of the public sector. This is because human resources constitute the ultimate basis for the wealth of nations rather capital income or material resources, which are passive factors of production. Human beings are the active agents who accumulate capital, exploit resources, and build socio- economic and political organizations for the development of its citizenry.

This paper is however divided into nine sections. Sections one and two comprised the introduction and the statement of problem. Sections three and four delve into the methodology and the conceptual clarification. Sections five and six capture the focus of capacity building for service delivery and status of public service delivery in Nigeria. Sections seven and eight consist of challenges to effective capacity building and recommendations, while section nine is the conclusion.

\subsection{Statement of Problem}

In recent times, the Nigerian civil service has come under serious criticisms for its epileptic, poor and inefficient service delivery. Civil servants are perceived as unprofessional, lethargic, incompetent and inexperienced (Fatile, 2013). Poor service delivery in the country constitutes a clog in the wheel of progress. The absence of a deliberate and systematic capacity building initiative for the entire public sector is responsible for the low productivity and inefficient service delivery experienced in the country. It will be difficult to achieve efficient service delivery in a situation where public servants are not adequately empowered with the requisite knowledge, skills and attitude in their workplace. The overall philosophy of the paper is to contribute to re-engineering of Nigerian Public Sector as a panacea for socio-political development and economic stability and overall well-being of the citizenry of Nigeria. 


\subsection{Methodology}

This section deals with the methodological approach employed in the study. The study consists mainly secondary data such as text books, journals, newspapers, magazines and online publications. Historical and descriptive approaches are employed for the analysis which aided in drawing relevant conclusions.

\subsection{Towards Conceptual Clarification}

Concepts are identified as the most basic tool science has at its disposal (Dinwerth \& Pattberg, 2006:186). Capacity building, public sector and civil service are the concepts in this paper. Thus, this section deals with the discourses of concepts as the foundation of its analysis (Akindele et al, 2012:175; Finnemore \& Sikkink, 1998: 891).

The concept of capacity building is subjected to different definitions and interpretations. In a generic sense, capacity building can be conceived as activities which strengthen the knowledge, abilities, skills and behavior of individuals and improve institutional structures and process such that the organization can efficiently meet its mission and goals in a sustainable way. In the same vein, it is defined as the capability to perform functions or work efficiently. Egonmwan (2002) sees capacity building as human resources development, institutional development and policy environment within which organizations operate and interact.

The human resources or personnel are expected to determine the performances or otherwise of the institution. The performance or lack of performance of the public sector is implacably reflected on the people as recipient of the outcome of decision (performance) of the sector. How the people react to public service of course is contingent on its performance. The performance of the public sector in turn is affected by the quality and quantum of human resources infused into it. Indeed, it can be said that capacity building is all it takes to strengthen the capacity of the public sector to perform its constitutional assigned functions. Egonmwan (2002) asserts that capacity building anchors on the following:

(1) The Organization,

- It enhances performance and increase productivity;

- It heightens morale among staff;

- It reduces cost because generations are performed economically and efficiently; and,

- It brings about organizational stability and flexibility to adapt to changes in technology, techniques and methods and other motivations.

The individual employees,

- It leads to the acquisition of more knowledge skills and appropriate attitudes;

- It enhances the chances of advancement within the organization; and

- It leads to more job satisfaction, increased earning and greater security.

The society,

- It enhances overall productivity leading to increase in national income; and,

- Financial Resources and capacity building.

The availability of disposable (financial) resources is germane to human resources development, institutional development as well as environmental policy output. This view specifically aligns with various reports of the United Nation Development Programme (UNDP) regarding capacity building (United Nations Committee of Experts on Public Administration, 2006; UNDP, 2009; UNDP, 2015). These reports laid claim to specific definitions, components and the current human development challenge of developing countries. First, capacity development is defined as creation of an enabling environment with appropriate policy and legal frameworks, institutional development including community participation (of women in particular), human resources development and strengthening of managerial systems (United Nations Committee of Experts on Public Administration, 2006:7). Apart from that, UNDP recognizes that capacity building is a long term, continuing process, in which all stakeholders (ministers, non-governmental organization, formal groups, professional associations etc. participate).

Second, capacity building is perceived to be more than training and includes the following elements:

(a) Human resource development, the process of equipping individuals with the understanding, skills and access to information, knowledge and training that enables them to perform effectively;

(b) Organizational development, the elaboration of management structures, processes and procedures, not only within organizations but also the management of relationships between the different organizations and sectors (public, private and community); and

(c) Institutional and legal framework development, making legal and regulatory changes to enable organizations, institutions and agencies at all levels and in all sectors to enhance their capacities.

Third, the concept has been further amplified by Philbin (1996) "as a process of developing and strengthening the skills, instincts, abilities processes and resources that organizations and communities need to survive, adopt, and thrive in the fast changing world."

Fourth is the organizational sense, capacity building can encompass governance, policy-centric leadership 
choice, vision and mission of the organization, strategies to accomplish them and the administration of human and financial resources. More often than not, it may include revenue generation that comprises taxation, fundraising, appeal funds, advocacy, partnerships etc.

Fifth, capacity building is equally conceived in relation to leadership development, advocacy skills, training / speaking abilities, technical skills, and other areas of personal and professional development (Linnell, 2003). Corroboratively, UNDP sees capacity development as the process through which individuals, organizations and societies obtain, strengthen and maintain the capabilities to set and achieve their own developmental objectives overtime (UNDP, 2009:5). In fact, the UN General Assembly has officially recognized the Human Development Report, which is strongly tied to capacity building, as "an independent intellectual exercise" that has become an independent tool for raising awareness about human development around the world (UNDP, 2015:7). A concern of worry in that report is the high prevalence of discrimination against ethnic groups in developing countries, and of course, Nigeria is not an exception. For example, labor outcomes of disadvantaged ethnic groups reflect different forms of inequality, restricted opportunities and discrimination throughout lifecycle (UNDP, 2015:38).

Finally, capacity building is described as transformative programme or process that empowers individuals, leaders, organizations and societies so as to bring about desirable change in a democratic setting. Intuitively, capacity building must respond to the changing needs of individuals, organizations, and the entire public sector.

\section{Public Sector}

The term public sector refers to all organizations that exist as part of government implementing policy decisions and delivering services. It is a mandatory institution under the Nigerian constitution of 1999 . The public sector in Nigeria is made up of the following:

(i) The civil service, which is often referred to as the core service and is composed of line ministries and extra ministerial agencies, and;

(ii) The public bureaucracy, which is composed of the enlarged public service including: (a) Services for the states and national assembly; (b) The judiciary; (c) The armed forces (d) The police and other security agencies (e) Para-military services (immigration, customs, prisons etc. (f) Parastatals and agencies including social service, commercial oriented agencies, regulatory agencies, educational institutions. The public sector is that part of the state that can be described as the organizational arm of government, charged with the analysis and implementation of public policy, as well as providing inputs into policy formulation. The civil service is the sub-system of the public sector (Omoyefa, 2008:28). The public sector is that part of the state that can be described as the organizational arm of government, charged with the analysis and implementation of public policy, as well as providing inputs into policy formulation. The civil service is the sub-system of the public sector.

\section{Civil Service}

The civil service is the bedrock upon which the government is seated and balanced. The civil service is one of the great political inventions of the nineteenth century England. As a concept, however, the term 'civil service' although commonly used is usually misunderstood and often misused as it really has no standard definition (Olaopa, 2008). Civil service refers to the machinery of government that is saddled with the entire business of government (Chipkin \& Gibert, 2012). It involves the totality of personnel entrusted with the day-to-day running of the administration of the state and the implementation of its policies. Civil service as a concept was borrowed from the British administration to describe a system where selection of staff is based on merit, professionalism and careerism (King, 2009).

From the foregoing, civil service refers to the body of permanent officials appointed to assist the political executive in formulating and implementing government policies. These officials are called civil servants. It also refers to the ministries and departments within which specific aspects of government works are carried out (Olaopa, 2008). The entire management of the civil service can be divided into:

(i) Junior Staff...................... on GL 01-06

(ii) Senior Staff....................... on GL 07and above

The senior staff can be further divided into two broad categories

(i) Senior Staff......................GL 07-12

(ii) Management Staff.................GL 13-16

GL 17 (Federal Level only)

The management staff comprises the leadership of the civil service and it is closest to the political leadership. The character and disposition of the management staff as well as their record of performance are crucial to the determination of the attitude of the political leadership to the service (Abiona \& Oladoyin, 2008).

\subsection{Focus of Capacity Building for Service Delivery}

According to Dada (2004), he maintained that in order to achieve effective implementation of service delivery, 
capacity building should focus on the following:

- Strategic Management

- Policy Development and Management

- Ethics of Good Governance

- Performance Management

- Human Resource Development and Management

- $\quad$ Target Setting

- Bench marking

- Project management

- Monitoring and Evaluation

- Entrepreneur development

- Team Building

- Managing and Leading Strategic Change

- E - Government and Management Information System

- Time Management

- Customer care

- Effective Communication skills

- Negotiation Skills and Management

- Total Quality Management

- Business Forces Re-engineering

- Change Management

- Crisis Management

- Creative Thinking

- Problem solving and Decision making

- Poverty Alleviation

- Investment Appraisal

- Reform Management

- Service Delivery, Performance and Customer focus.

Capacity building in Nigeria, like in most developing countries is not a well-defined practice. The World Bank has traditionally treated public sector capacity building as a collateral objective, rather than as a goal in its own right.

\subsection{Status of Public Service Delivery in Nigeria}

The colonial administration in Nigeria between 1914 and 1954 were not directly involved in the delivery of public services. Their roles were regulatory, setting of performance standards, establishment of model institutions, provision of grants to private service providers and defense. The overall assessment of public service delivery in Nigeria is below average. Even without recourse to any research or literature, the failure of Nigeria Airways, the collapse of the Nigerian Railway system, the erratic power supply, incessant strikes by health workers and university lecturers, among others confirm the below-average rating (Fagbemi, 2006: 53).

In view of a presented speech of former President Olusegun Obasanjo to show the deplorable level of service delivery in Nigeria and the need for change in the way public officers render service to the public, Fagbemi (2006:65, cited Obasanjo, 2004) notes that:

....Regrettably, Nigerians have for too long been feeling short-changed by the quality of public service delivery. Our public offices have for too long been showcases for the combined evils of inefficiency and corruption, whilst being impediments to effective implementation of government policies...

There are many causes of poor service delivery in Nigeria. Among these are: mismanagement and misappropriation of public funds, poor training and manpower development, inadequate motivation etc. The state of public service delivery in Nigeria has been well documented (Wendy, 2004).

A major hindrance or obstacle to efficient service delivery in Nigeria is the attitude of public servants to members of the public. Most public servants are not well trained on how to relate with their clients. Customers are the direct users of services delivered by government agencies. The concept of customer service delivery, therefore, emanates from the perceived need to treat members of the public that require government services, like a privatesector entrepreneur would treat his/her customers (Fagbemi, 2006).

7.0. Challenges or Factors Affecting Effective Capacity Building in Nigeria

A critical appraisal of capacity building and public service delivery in Nigeria cannot be sufficiently discussed 
without identifying the associated challenges. The following challenges are identified in this paper:

First is inadequate budgetary allocation for training. Training has always been the least funded budget item in the enlarged public service. The failure of government at the various tiers to invest heavily in public sector training has affected service delivery in the country. In other words, budgetary allocation towards effective and efficient public servants' training has not always been adequate

Second is lack of political will on the part of government and common understanding of the importance of capacity building which is responsible for the non-systemic and ad-hoc training method.

Third is bias training: In the public sector, training is not job-focused. It is observed that two most common influences are welfare and political considerations. In this respect, the same groups of people keep attending training programs because of their closeness to top political functionaries.

Fourth is that capacity building in the Nigerian public service lacks a fully articulated framework for assessing capacity needs, designing and sequencing appropriate interventions, and determining results.

\subsection{Recommendations}

There is the need for an urgent re-assessment of the relevance of the training polices in the Nigerian civil service. Civil servants must be mandated to attend at least one training programme per year. Trainers should be made to submit a report as well as share experienced with colleagues in their department as to what they learn from the training that can be useful to them. Report should include an Action Plan.

The three tiers of government should allocate a sizeable proportion of their annual budget to capacity building effort in all critical sectors of the economy so as effectively meet up the manpower demands. The various tiers of government should put effective mechanisms in place for monitoring budgetary allocations.

The Federal government must implement the recommendations of the Steve Oronsoye's Presidential panel recommendations on the merger, rationalization and restructuring of Federal government's Ministries, Departments and Agencies (MDA's) must be implemented. This will ensure better coordination and synergy in the fight against corruption and inefficient service delivery.

There must be reform in the educational sector. The educational sector must be made to include entrepreneurship studies and skills development in primary, secondary and tertiary institutions in the academic curriculum so as to fight against poverty and unemployment and also develop and sustain her capacity building process.

\subsection{Conclusion}

This work wants to conclude on the note that sustainability of capacity building in the public sector must be allembracing. It has to take cognizance of human and material resources for it to endure. Secondly, the democratic process in Nigeria must be strengthened through purposive governance, accountability and periodic electoral process to gauge the input and output mechanism of the political institutions.

\section{Bibliography}

Abiola, F. O. amd Oladoyin, A. M. (2008).From Policy to Result-Based Implementation. Anniversary Lecture, Nigerian Public Service Week in Osun State, Osogbo: Atman Publishers.

Aborisade, O. and Aransi, I.O. (2006). State and Local Government in Nigeria: The Changing Scene. USA: Catawba Publishing Company.

Akindele, S.T. Adeyemi, O.O. \& Aluko, O.A. (2012). Democracy, Governance, Legislative Challenges and Impediments in Nigeria, 1999-2011. Journal of Politics and Law, Vol. 5, No. 2.

Ale, O. (2005). Model Administration Law for Nigerian Local Government, 1976 - 2004. Ado-Ekiti: Ola Olu Printers.

Awotokun. K, (2007). The Challenge of Nigeria Local Governments in the $21^{\text {st }}$ Century.International Conference Organized by Faculty of Administration, Obafemi Awolowo University, Ile-Ife, Nigeria.

Awotokun K, (2003). Local Government under the 1999 Constitution in Nigeria. Journal of Social Sciences. India.

Awotokun . K. (1998). Governance and Legislative Control in Nigeria: Lesson from the Second and Third Republics. San Francisco: International Scholars Publications.

Constitution of Federal Republic of Nigeria (1999). Constitution of Federal Republic of Nigeria. Abuja: Government Press. Retrieved from: http://www.un.org/esa/coordinationpublicmulti.html (Accesed, $5 / 30 / 2016)$

Constitution of Federal Republic of Nigeria (1989). Constitution of Federal Republic of Nigeria. Lagos: Government Press. Retrieved from: http://www.un.org/esa/coordinationpublicmulti.html (Accesed, $5 / 30 / 2016)$

Constitution of Federal Republic of Nigeria (1979).Constitution of Nigeria. Lagos:

Federal Ministry of Information. Retrieved from: http://www.un.org/esa/coordinationpublicmulti.html (Accesed, 


$$
5 / 30 / 2016)
$$

Dada, J. O. (2004). Effective Human Resource Management through Team Building. Paper Presented at the OneDay Seminar for Members of Dental Technologist Registration Board. Lagos, Nigeria.

Dingwerth, K. and Pattberg, P. (2006).Global Governance as a Perspective on World Politics. Global Governance 12 , pp. 186.

Egonmwan J. A. (2002). Human Capacity Building and Local Government. In: Okon E.U. \& James O. Local Government Administration and Grassroots Democracy in Nigeria. Calabar : University of Calabar Press.

Ekeh, P. P. (1975). Colonialism and the two publics in Africa: A Theoretical Statement. Comparative Studies in Society and History. Vol. 17.1.

Fagbemi, A. (2006). Customer Service Delivery in Public Management. Lagos: Concept Publication Limited

Fatile, J.O. (2013). Ethics and Performance in the Nigerian Public Sector. Retrieved from: www.garph.co.uk Vol.2/No.10/October IJARMSS/132. (Accessed. 5/30/2016)

Federal Republic of Nigeria (2004). Technical Report on Finance and Administration of Local Government. Abuja: The Presidency.

Federal Republic of Nigeria (1976).Guidelines on 1976 Local Government Reforms. Kaduna: Government Printer. Finnemore, M. \& Sikkink, K. (1998). International Norm Dynamics and Political Change. International Organisation 52, 4, Autumn, pp.891.

Ikogho, O. P. (1993). Nigerian Constitution Simplified. Abeokuta: Law Angle Consult.

Mabogunje A.I, (1995). Local Government and the concept of Social Capital. Ibadan: Development Policy Centre.

Linnell, D. (2003). Evaluation of Capacity Building: Lessons from the Field. Washington DC: Alliance for Nonprofit Management.

Oji, G.O. (2002). Capacity Building for sustainable government. In: Okon E.U. \&James O. Local Government Administration and Grassroots Democracy in Nigeria, University of Calabar Press, Calabar.

Omoyela, P. S. (2008). Public Sector Refroms in Africa: A Philosophical Re-thinking. Africa Development, XXXIII(4): $15-30$.

Philbin, A. (1996). Capacity Building in Social Justice Organizations. Ford Foundation.

United Nations Development Programme (2015).Human Development Report 2015: Work for Human Development. New York: United Nations Development Programme.

United Nations Development Programme (2009). Capacity Development: A UNDP Primer. New York: United Nations Development Programme.

United Nations Committee of Experts on Public Administration (2006). Definition of Basic Concepts and Terminologies on Governance and Public Administration. New York: Committee of Experts on Public Administration of United Nations Fifth Session.

Wendy, T. (2004). Delivering Service in Nigeria: A Roadmap. London: Office of Public Service Reform. 